\title{
Microautoradiography-based enumeration of bacteria with estimates of thymidine-specific growth and production rates
}

\author{
Donald J. Douglas ${ }^{1, *}$, James A. Novitsky ${ }^{2} \&$ Robert O. Fournier ${ }^{1}$ \\ ${ }^{1}$ Department of Oceanography and ${ }^{2}$ Biology Department, Dalhousie University, Halifax, Nova Scotia B3H 4J1, Canada
}

\begin{abstract}
Autoradiography was used to enumerate cells at a variety of locations off Nova Scotia, Canada. The results indicated that greater numbers of cells incorporated ${ }^{3} \mathrm{H}$-glutamate than ${ }^{3} \mathrm{H}$ thymidine. This pattern was consistent among different locations and within depth profiles collected at a station over the slope region. Bacterial production, calculated from thymidine incorporation, varied from 0.8 to $2.73 \mu \mathrm{g} \mathrm{C} \mathrm{l}^{-1} \mathrm{~d}^{-1}$. This was equivalent to 2 to $33 \%$ (average: $13 \%$ ) of primary production. Growth rates of thymidine-incorporating bacteria were 0.86 to $1.8 \mathrm{~d}^{-1}$. Large variations in proportions of active bacteria among stations were observed. There was strong covariation within depth profiles among total bacterial abundance, numbers of substrate-active cells, bacterial production and primary production. These findings suggest close coupling between phytoplankton and bacterial growth and production.
\end{abstract}

\section{INTRODUCTION}

Until recently, methods allowing determination of the abundance and production rates of marine bacteria have not been available. This has meant that the relationships between bacteria and other biological and physical variables in marine environments have remained largely uncharacterized. The use of epifluorescent microscopy with stains including acridine orange (Zimmermann \& Meyer-Reil 1974, Daley \& Hobbie 1975) and DAPI (Coleman 1980, Porter \& Feig 1980) have allowed total cell numbers to be assessed. Radiotracer incorporation of nucleic acid precursors (Karl 1979, Fuhrman \& Azam 1980, 1982, Karl et al. $1981 a, b)$, have produced information on rates of microbial synthesis.

One shortcoming of both direct count and incorporation studies is that they yield no information on the metabolic activity of the individual cells within a population. Autoradiography has been used by several groups to identify bacteria active with respect to individual substrates (Brock 1967, Ramsay 1974, Peroni \&

\footnotetext{
- Present address: Institute of Ecology, University of Georgia, Athens, Georgia 30602, USA
}

Lavarello 1975, Hoppe 1976, 1977. Faust \& Correll 1977). More recently, methods have been proposed which combine autoradiography with epifluorescence to resolve cells which assimilate labelled substrates (Meyer-Reil 1978, Tabor \& Neihof 1982, 1984, Bailey et al. 1983, Riemann et al. 1984).

We report here the results of a study using autoradiography to enumerate bacteria which incorporated ${ }^{3} \mathrm{H}$-glutamate and ${ }^{3} \mathrm{H}$-thymidine in water samples collected from several different environments. Glutamate was chosen as an indicator of heterotrophically active bacteria as both theoretical and empirical evidence show that this amino acid is incorporated at relatively high rates by many marine bacteria (Griffiths et al. 1977. Novitsky 1983a). Thymidine was selected because it has been used for estimation of bacterial production in many studies (e.g. Fuhrman \& Azam 1980, 1982, Ducklow et al. 1982, Newell \& Fallon 1982, Ducklow \& Kirchman 1983, Ducklow \& Hill 1985a, b).

Because one assumption that is critical to nucleic acid precursor studies is that all growing bacteria (and only bacteria) incorporate the substrate, the question of the universality of thymidine uptake is of substantial importance. Our approach was to test the generality of thymidine incorporation by natural populations in a variety of marine environments. 
Data on the abundance of thymidine-active cells have been combined with ${ }^{3} \mathrm{H}$-thymidine incorporation rates to estimate growth rates of bacteria. These results are discussed within the context of spatial covariation of abundance and production of bacteria with phytoplankton.

\section{METHODS AND MATERIALS}

Water samples were collected off the coast of Nova Scotia, Canada, during the period 2 to 11 June 1982, at several locations (Fig. 1) selected to provide a variety of environments. These included 2 coastal stations, SS 26 and 29, 2 stations over the slope region, SS 9 and 55 and a station, SS 13, near the center of a warm core Gulf Stream ring (82-G; Wroblewski \& Cheney 1984). During the sampling period, temperature and salinity were $6.5^{\circ} \mathrm{C}$ and $31.5 \%$ at the coastal stations; 7.5 to $10^{\circ} \mathrm{C}$ and 32.2 to $33.0 \%$ at the slope stations; and $19.5^{\circ} \mathrm{C}$ and $36.0 \%$ at the eddy station. A description of the physical environment and plankton dynamics of this region has been presented by Fournier et al. (1977).

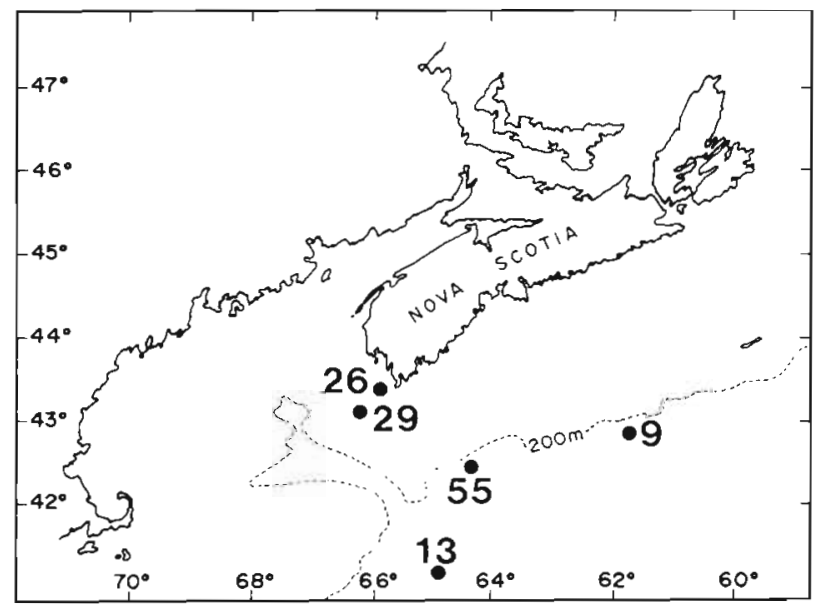

Fig. 1. Sampling locations off eastern Canada

Water samples were collected with 51 Niskin bottles at depths corresponding to the $50 \%$ light level at all stations. Samples for the following determinations were taken: chlorophyll a, primary production, acridine orange direct counts (AODC), thymidine incorporation and autoradiography, At Stn SS 9, the sampling location was marked with a drogue set in the upper mixed layer and samples were collected at ca $1000 \mathrm{~h}$ (local time) on 2 consecutive days. The depths sampled corresponded to the $100,30,15,9.5,6,3$ and $1 \%$ light levels as determined using a Secchi disc. Two aphotic zone samples, 60 and $75 \mathrm{~m}$, were also collected.

Chlorophyll a concentration was determined fluo- rometrically on samples collected on Whatman GF/F filters using the method of Strickland \& Parsons (1972).

Measurements of primary production were made by adding $5 \mu \mathrm{Ci}$ of $\mathrm{H}^{14} \mathrm{CO}_{3}^{-}$(New England Nuclear, 40 to $60 \mathrm{mCi} \mathrm{mmol}^{-1}$ ) to samples in $125 \mathrm{ml}$ Pyrex B.O.D. bottles. Two light and one opaque bottle were incubated for $24 \mathrm{~h}$ for each sample under simulated in situ light conditions. Following incubation, the contents were filtered (Whatman $\mathrm{GF} / \mathrm{F}$ ) and primary production was calculated (Strickland \& Parsons 1972).

Acridine orange cell counts were made using the method of Zimmermann \& Meyer-Reil (1974) adapted as follows. Samples were filtered onto pre-stained (Sudan Black; Sigma S-2380, 1: 15000 in 50\% ethanol for 24 to $48 \mathrm{~h}$ ) $0.2 \mu \mathrm{m}$ pore-size Nuclepore filters. A second filter (Millipore HA) was placed underneath to facilitate dispersion of the bacteria over the filter surface. After 3 min of staining (Sigma A-6014, $0.1 \%$ final conc.), the excess stain was drawn through and the filter was air dried. Filter sections were mounted in immersion oil (Cargille Type A) and cells were counted at $1250 \times$ magnification with an epifluorescence-equipped (exciter filter, 450 to $490 \mathrm{~nm}$; beam splitter, $510 \mathrm{~nm}$; suppression filter, $515 \mathrm{~nm}$ : Leitz filter pack I2) Wild Leitz Dialux 20 EB microscope.

Bacterial production was estimated using the method of Fuhrman \& Azam (1980). ${ }^{3} \mathrm{H}$-thymidine (New England Nuclear, specific activity: $77.2 \mathrm{Ci}$ $\mathrm{mmol}^{-1}, 5 \mathrm{nM}$ final concentration) was added to $20 \mathrm{ml}$ water samples which were incubated in the dark at within $1.0 \mathrm{C}^{\circ}$ of in situ temperature for 8 to $10 \mathrm{~h}$. Macromolecules were precipitated using ice-cold $5 \%$ trichloroacetic acid (TCA) and were collected on Millipore HA filters. The filters were rinsed 5 times with ice-cold TCA and then placed in scintillation vials with $10 \mathrm{ml}$ of Aquasol 2 (New England Nuclear). Radioactivity was counted on a LKB Racbeta liquid scintillation counter. Samples were run in duplicate; time-zero blanks were subtracted from sample measurements. Bacterial production was estimated from ${ }^{3} \mathrm{H}$ thymidine incorporation rate using the factor $2 \times 10^{18}$ cells per mole thymidine and assuming that $65 \%$ of the incorporated thymidine was present in DNA (Fuhrman \& Azam 1982). Bacterial carbon production was calculated based on an average cell volume of $0.10 \mathrm{\mu m}^{3}$, which was determined from acridine orange stained samples, and a carbon-to-cell volume ratio of $121 \mathrm{fg} \mathrm{C}$ $\mu \mathrm{m}^{-3}$ (Watson et al. 1977).

Growth rates $\left(\mathrm{d}^{-1}\right)$ of thymidine-incorporating bacteria were estimated using the relation:

Growth rate $=\frac{\text { bacterial production }\left(\text { cells } \mathrm{I}^{-1} \mathrm{~d}^{-1}\right)}{\text { thymidine-active bacteria }\left(\text { cells } \mathrm{I}^{-1}\right)}$

Autoradiograms were prepared using the method of Meyer-Reil (1978) as modified and described by Doug- 
Fig. 2. Autoradiograms of cells labelled with (A) ${ }^{3} \mathrm{H}$-thymidine and (B) ${ }^{3} \mathrm{H}$-glutamate. (Bar length $=5 \mu \mathrm{m})$
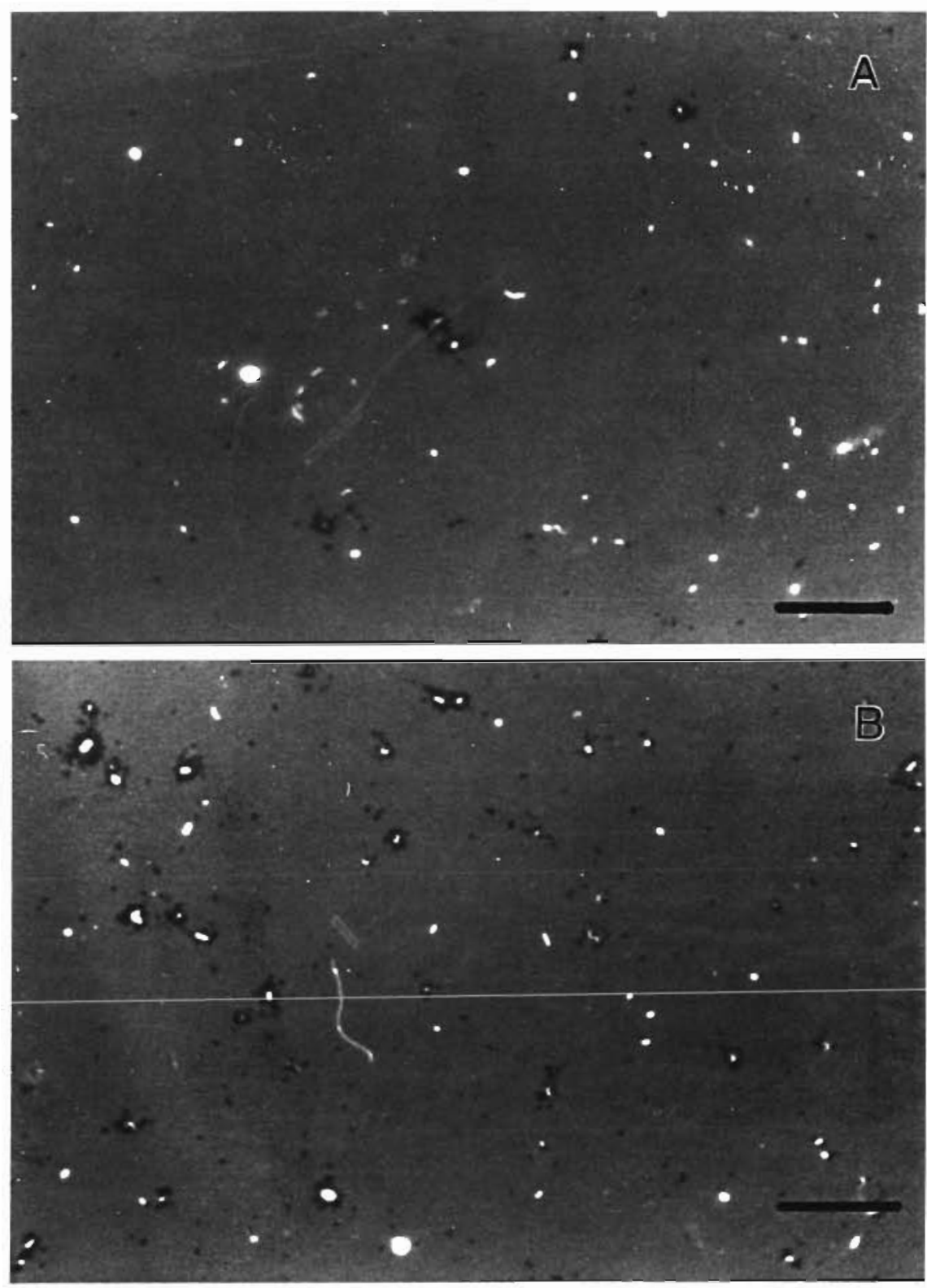

\section{RESULTS}

las (1984). The substrates and concentrations used were: L-[3,4- ${ }^{3} \mathrm{H}$-]glutamic acid (New England Nuclear, specific activity: $44.0 \mathrm{Ci} \mathrm{mmol}^{-1} ; 3.4 \mathrm{nM}$ final conc.) and [methyl ${ }^{3} \mathrm{H}$ ] thymidine (New England Nuclear, specific activity: $77.2 \mathrm{Ci} \mathrm{mmol}{ }^{-1} ; 5 \mathrm{nM}$ final conc.). Autoradiography samples were incubated at the same temperature and for the same length of time as corresponding samples for measurements of bacterial productivity. Cells were counted if they had exposed a minimum of 3 silver grains. In almost all cases more grains were exposed, creating a halo around the labelled cells (Fig. 2). Labelled cells from $\geq 20$ microscope fields were counted for each sample. The mean cell abundance and the $95 \%$ confidence interval ( $\mathrm{CI}$ ) of the mean were calculated.

\section{Abundance of glutamate- and thymidine-active cells}

Autoradiograms of samples incubated with ${ }^{3} \mathrm{H}$-thymidine and ${ }^{3} \mathrm{H}$-glutamate revealed that many of the cells present were labelled with exposed silver grains (Fig. 2). The substrate-active cells ranged in size from cocci of ca 0.2 to $0.5 \mu \mathrm{m}$ in diameter to bacilli of up to several micrometers in length. There were, however, small numbers of relatively large (ca 0.8 to $1.4 \mu \mathrm{m}$ ), bright fluorescing ovoid or spherical cells which did not incorporate either substrate. These unlabelled cells appeared to correspond, at least in part, to the photosynthetic picoplankton described by Douglas (1984). 
Table 1. Abundance of substrate-active cells. GACC and TACC: glutamate- and thymidine-active cell counts (units: cells $\times 10^{5} \mathrm{~m}^{-1}$ ); \% AODC: percent of acridine orange direct counts; $\mathrm{CI}$ : confidence interval; NS: no sample; SE: standard error

\begin{tabular}{|lcccc|}
\hline & \multicolumn{2}{c}{ Glutamate } & \multicolumn{2}{c}{ Thymidine } \\
Location & GACC & $\%$ & TACC & $\%$ \\
& & AODC & & AODC \\
& $\bar{X}( \pm 95 \% \mathrm{CI})$ & & $\overline{\mathrm{X}}( \pm 95 \% \mathrm{CI})$ & \\
\hline Coastal & & & & \\
SS 26 & $\mathrm{NS}$ & - & $0.81( \pm 0.18)$ & 16.8 \\
SS 29 & $2.29( \pm 0.56)$ & 69.4 & $0.37( \pm 0.08)$ & 11.2 \\
Slope & & & & \\
SS 9 & $5.12( \pm 0.53)$ & 41.3 & $1.31( \pm 0.20)$ & 10.6 \\
SS 55 & $4.17( \pm 0.48)$ & 35.6 & $0.74( \pm 0.13)$ & 6.3 \\
Eddy & & & & \\
SS 13 & $4.27( \pm 1.01)$ & 97.0 & $0.81( \pm 0.09)$ & 18.5 \\
Overadl & & & & 12.7 \\
$\bar{X}$ & 3.96 & 60.8 & 0.81 & 2.2 \\
SE & 0.60 & 14.1 & 0.15 & \\
\hline
\end{tabular}

Table 2. Percent of cells labelled and activity-per-cell

\begin{tabular}{|lccc|}
\hline \multicolumn{1}{|c}{ Location } & $\begin{array}{c}\text { Depth } \\
(\mathrm{m})\end{array}$ & $\begin{array}{c}\text { \% of cells } \\
\text { labelled }\end{array}$ & $\begin{array}{c}\text { Kdprn-per } \\
10^{6} \text { cells }^{1}\end{array}$ \\
\hline Thymidine & & & \\
SS 9 & 0 & 16.5 & 26.6 \\
& 8 & 10.6 & 58.6 \\
& 18 & 10.2 & 60.9 \\
& 25 & 6.8 & 89.4 \\
& 30 & 8.2 & 71.5 \\
& 37 & 7.4 & 50.0 \\
& 49 & 8.6 & 44.2 \\
SS 13 & 60 & 11.2 & 20.8 \\
SS 26 & 75 & 5.9 & 29.2 \\
SS 29 & 8 & 13.5 & 60.7 \\
SS 55 & 4 & 16.8 & 27.2 \\
Glutamate & 3 & 11.2 & 56.8 \\
SS 9 & 4 & 6.3 & 54.2 \\
& & & \\
'Kdpm $=$ dpm $\times 1000$ & 46.3 & 16.9 \\
& & & \\
\hline
\end{tabular}

Occasionally, larger phytoplankton, including diatoms and dinoflagellates, were observed in the samples. These were, almost without exception, free of silver grains. In the few cases where there were exposed silver grains on algal cells, the grains appeared to be associated with bacteria located on the algae.

Glutamate-active cell counts (GACC) varied from 2.29 to $5.12 \times 10^{5}$ cells $\mathrm{ml}^{-1}$ (Table 1 ). Thymidineactive cell counts (TACC) were 0.37 to $1.31 \times 10^{5}$ cells $\mathrm{ml}^{-1}$; they were consistently lower than corresponding counts of glutamate-incorporating cells (Table 1). The average percentages of glutamate- and thymidineactive cells relative to AODC were 60.8 and $12.7 \%$, respectively.

The activity in samples incubated with ${ }^{3} \mathrm{H}$-thymidine varied from 20.8 to $89.4 \mathrm{Kdpm}$ per $10^{6}$ cells (Table 2). There was no tendency for low percent of cells labelled to correspond with low values of activityper-cell $\left(\mathrm{r}^{2}=0.19\right.$; not significant at $\left.\mathrm{p}<0.05\right)$. Incorporation measurements using ${ }^{3} \mathrm{H}$-glutamate were not done routinely. However, an experiment conducted at 2 depths at Stn SS 9 indicated that glutamate-incorporating bacteria were characterized by a lower dpmper-cell than cells which incorporated thymidine (Table 2).

Neither substrate was taken up in control incubations (cells killed at time zero). However, background silver grain density in the controls was consistently lower than in live samples. This difference may have resulted from production of insoluble radioactive extracellular products by bacteria. In any case, the background was evenly distributed and did not cause difficulty in identifying labelled cells.

\section{Thymidine incorporation and bacterial growth rates}

Thymidine incorporation rates at the $50 \%$ light level varied from 1.37 pmol $\mathrm{l}^{-1} \mathrm{~h}^{-1}$ at one coastal station (SS 26) to a maximum of $4.72 \mathrm{pmol} \mathrm{l}^{-1} \mathrm{~h}^{-1}$ at the slope station, SS 9 (Table 3). These data correspond to bacterial production of 0.80 to $2.73 \mu \mathrm{g} \mathrm{C} \mathrm{l}^{-1} \mathrm{~d}^{-1}$. Incorporation of ${ }^{3} \mathrm{H}$-thymidine over the incubation period averaged $0.58 \%$ (range: 0.02 to $1.6 \% ; n=42$ ) of the substrate added. Cell growth rates, calculated by normalizing thymidine-based production rates to thymidine-active cell counts, varied from 0.86 to $2.0 \mathrm{~d}^{-1}$ (Table 3).

\section{Vertical distribution of abundance, production and growth of substrate-active cells}

At the slope station, SS 9, counts of substrate-active cells, bacterial production and cell growth rates were maximum in the upper euphotic zone, decreasing with depth below 25 to $30 \mathrm{~m}$ (Table 4; Fig. 3). Glutamateand thymidine-active cell counts, bacterial production and growth rates at the $50 \%$ light depth were $6.5,6.6$, 27 , and 4.3 times greater than corresponding values at $75 \mathrm{~m}$.

Counts of glutamate-incorporating cells were consistently greater than those based on thymidine incorporation at all depths sampled. Numbers of glutamateand thymidine-active cells relative to total cell counts averaged 33.0 and $9.5 \%$, respectively (Table 4). 
Table 3. Thymidine incorporation, bacterial production and growth rate. B:P prod: bacterial production expressed as a percentage of primary production; NRS: no replicate sample; SE: standard error

\begin{tabular}{|c|c|c|c|c|}
\hline Location & $\begin{array}{c}\text { Thymidine } \\
\text { incorpora- } \\
\text { tion (pmol } \\
\left.1^{-1} \mathrm{~h}^{-1}\right)\end{array}$ & $\begin{array}{c}\text { Bacterial } \\
\text { production } \\
\left(\mu \mathrm{gC} 1^{-3} \mathrm{~d}^{-1}\right)\end{array}$ & $\begin{array}{c}\text { B:P } \\
\text { prod } \\
(\times 100)\end{array}$ & $\begin{array}{c}\text { Growth } \\
\text { rate } \\
\left(\mathrm{d}^{-1}\right)\end{array}$ \\
\hline \multicolumn{5}{|l|}{ Coastal } \\
\hline SS 26 & $1.44(0.04)$ & $0.84(0.01)$ & 2.5 & 0.86 \\
\hline SS 29 & 1.37 (NRS) & 0.80 & 2.3 & 1.8 \\
\hline \multicolumn{5}{|l|}{ Slope } \\
\hline SS 9 & $4.72(0.03)$ & $2.73(0.11)$ & 33.0 & 1.7 \\
\hline SS 55 & $2.44(0.02)$ & $1.42(0.06)$ & 1.9 & 1.6 \\
\hline \multicolumn{5}{|l|}{ Eddy } \\
\hline SS 13 & $3.44 \quad(0.02)$ & $2.00(0.04)$ & 23.1 & 2.0 \\
\hline \multicolumn{5}{|l|}{ Overall } \\
\hline X & 2.68 & 1.56 & 12.6 & 1.6 \\
\hline SE & 1.20 & 0.37 & 6.5 & 0.20 \\
\hline
\end{tabular}

Although there were fewer active cells at depth, the proportion of active cells relative to total cell counts did not vary with a consistent pattern (Table 4).

Bacterial production through and immediately

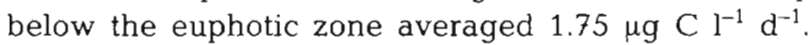
Bacterial production constituted an average of $33 \%$ of primary production above the $1 \%$ light depth (Table 4).

\section{DISCUSSION}

\section{Autoradiography}

Bacteria of the range of size and morphology observed with epifluorescent microscopy (Ferguson \&

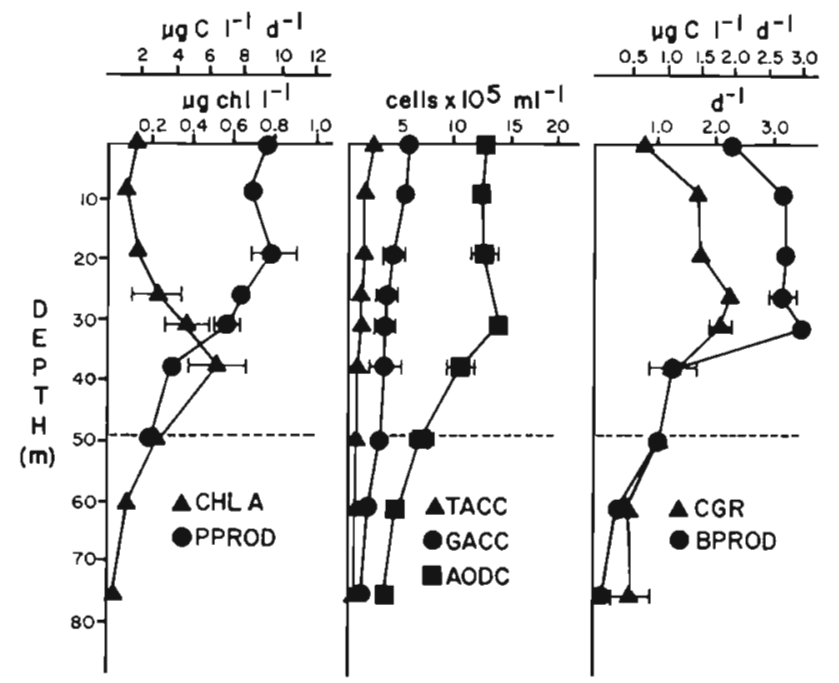

Fig. 3. Vertical profiles of chlorophyll a, primary production, substrate-active cells, bacterial production and cell growth rates at slope station, SS 9. CHL A: chlorophyll $a_{i}$ PPROD: primary productivity; TACC and GACC: thymidine and glutamate active cell counts; AODC: acridine orange direct counts; CGR: cell growth rate; BPROD: bacterial productivity. Error bars: primary productivity, range of duplicate samples; remaining variables, range of 2 profiles collected $24 \mathrm{~h}$ apart.

Dashed line: $1 \%$ light depth

Rublee 1976, Zimmermann 1977, Ferguson \& Palumbo 1979, Fuhrman 1981) incorporated ${ }^{3} \mathrm{H}$-glutamate and ${ }^{3} \mathrm{H}$-thymidine. This result, and the virtual lack of labelling of algal cells, supports conclusions based on kinetic and size-fractionation studies (see e.g. review by Van Es \& Meyer-Reil 1982) in establishing that bacteria are responsible for the bulk of incorporation of dissolved organic substrates in marine environments. The autoradiography results also strengthen the argument that thymidine incorporation is specific to bac-

Table 4. Abundance, thymidine incorporation and growth rates of substrate-active cells at the slope station, SS 9. Units: GACC and TACC, cells $\times 10^{5} \mathrm{ml}^{-1}$; TdR incorporation, pmol $\mathrm{l}^{-1} \mathrm{~h}^{-1}$; growth rate, $\mathrm{d}^{-1}$. B:P prod: bacterial production expressed as a percentage of primary production; SE: standard error

\begin{tabular}{|c|c|c|c|c|c|c|c|}
\hline \multirow[t]{2}{*}{ Depth } & \multicolumn{2}{|c|}{ Glutamate } & \multicolumn{2}{|c|}{ Thymidine } & \multirow[t]{2}{*}{ Bact prod } & \multirow[t]{2}{*}{ B:P prod } & \multirow[t]{2}{*}{ Growth rate } \\
\hline & GACC & $\%$ AODC & TACC & $\%$ AODC & & & \\
\hline 0 & 5.76 & 44.3 & 2.14 & 16.5 & 1.95 & 22.1 & 0.74 \\
\hline 8 & 5.12 & 41.3 & 1.31 & 10.6 & 2.73 & 33.0 & 1.73 \\
\hline 18 & 4.06 & 31.5 & 1.31 & 10.2 & 2.80 & 29.3 & 1.78 \\
\hline 25 & 3.44 & 23.9 & 0.98 & 6.8 & 2.71 & 35.1 & 2.28 \\
\hline 30 & 3.32 & 27.9 & 1.19 & 8.2 & 3.04 & 44.2 & 2.12 \\
\hline 37 & 3.23 & 30.5 & 0.90 & 7.4 & 1.11 & 30.1 & 1.32 \\
\hline 49 & 2.88 & 42.3 & 0.68 & 8.6 & 0.93 & 38.4 & 1.09 \\
\hline 60 & 1.72 & 37.4 & 0.51 & 11.2 & 0.36 & 1 & 0.58 \\
\hline 75 & 0.79 & 23.2 & 0.20 & 5.9 & 0.10 & t & 0.40 \\
\hline \multicolumn{8}{|l|}{ Overall } \\
\hline$\overline{\mathrm{X}}$ & 3.37 & 33.0 & 1.02 & 9.5 & 1.75 & 33.0 & 1.36 \\
\hline $\mathrm{SE}$ & 0.51 & 2.9 & 0.19 & 1.0 & 0.38 & 2.8 & 0.22 \\
\hline
\end{tabular}


Table 5. Abundance of substrate-active cells; comparison with literature values. AA: amino acid mixture; NR: not reported

\begin{tabular}{|c|c|c|c|c|}
\hline Location & Substrate & $\begin{array}{l}\text { Abundance } \\
\left(\times 10^{5} \mathrm{ml}^{-1}\right)\end{array}$ & $\%$ AODC & Source \\
\hline Bay of Kiel & $A A$ & 19 & 41 & Hoppe 1976 \\
\hline Kiel Fjord & Glucose & $1.2-32.5$ & $2.3-56.2$ & Meyer-Reil 1978 \\
\hline Scripps Pier & $\begin{array}{l}\text { Glucose } \\
\text { AA } \\
\text { Thymidine }\end{array}$ & $\begin{array}{l}\text { NR } \\
\text { NR } \\
\text { NR }\end{array}$ & $\begin{array}{l}45 \\
46-52 \\
34-52\end{array}$ & Fuhrman \& Azam 1982 \\
\hline Chesapeake Bay ${ }^{1}$ & $\begin{array}{l}\text { Acetate } \\
\text { AA } \\
\text { Thymidine }\end{array}$ & $\begin{array}{l}50: 69 \\
71: 75 \\
106: 120\end{array}$ & $\begin{array}{l}34.5: 47.6 \\
47.6: 50.3 \\
67.33: 75.5\end{array}$ & Tabor \& Neihof 1982 \\
\hline Chesapeake Bay & AA & $10-156$ & $7.8-87.1$ & Bailey et al. 1983 \\
\hline Halifax Harbour & $\begin{array}{l}\text { Glucose } \\
\text { Glutamate } \\
\text { Thymidine }\end{array}$ & $\begin{array}{l}0.08-2 \\
2-6 \\
1-1.2\end{array}$ & $\begin{array}{l}0.9-16.0 \\
20.3-35.2 \\
9.2-19.7\end{array}$ & Novitsky 1983a \\
\hline Danish fjord & Thymidine & $7.0-10.3$ & $20-80$ & Riemann et al. 1984 \\
\hline $\begin{array}{l}\text { Nova Scotia } \\
\text { Coastal } \\
\text { Slope } \\
\text { Eddy }\end{array}$ & $\begin{array}{l}\text { Glutamate } \\
\text { Glutamate } \\
\text { Glutamate }\end{array}$ & $\begin{array}{l}2.29 \\
0.79-5.76 \\
4.27\end{array}$ & $\begin{array}{l}69.4 \\
23.2-44.3 \\
97.0\end{array}$ & Present study \\
\hline $\begin{array}{l}\text { Coastal } \\
\text { Slope } \\
\text { Eddy }\end{array}$ & $\begin{array}{l}\text { Thymidine } \\
\text { Thymidine } \\
\text { Thymidine }\end{array}$ & $\begin{array}{l}0.37-0.81 \\
0.20-2.14 \\
0.81\end{array}$ & $\begin{array}{l}11.2-16.8 \\
5.9-16.5 \\
8.8\end{array}$ & \\
\hline
\end{tabular}

teria (Fuhrman \& Azam 1982) over a variety of marine environments.

Since many of the smaller cocci incorporated the radiolabelled substrates, there was no evidence that the metabolism of these cells was shut down as has been observed for cells of similar appearance resulting from laboratory-induced starvation (Novitsky \& Morita $1976,1977)$. There was, however, evidence that a substantial portion of cells was not active in incorporation of the 2 substrates tested. If the most conservative possibility is assumed, i.e. the bacteria incorporating glutamate and thymidine represent independent populations, the number of substrate-active cells would still constitute a minority of direct cell counts in the upper water column at Stn SS 55 (Table 1) and at most depths sampled at Stn SS 9 (Table 3).

Because counts of substrate-active cells are minimum estimates of total metabolically-active bacteria (see below), our results do not prove that a majority of cells was dormant. The wide range in percent of total bacteria which were active with respect to glutamate and thymidine does suggest, however, that there is considerable variation in the proportion of bacteria which are metabolically active in different natural habitats.

There are few data available on abundance of sub- strate-active bacteria for comparison with the results of this research. Virtually all studies combining autoradiography with organic substrates have used either single species (Brock 1967, Ramsay 1974) or have been conducted in estuarine or eutrophic nearshore environments (Hoppe 1976, 1977, Meyer-Reil 1978, Tabor \& Neihof 1982, 1984, Bailey et al. 1983, Novitsky 1983a). The abundance of both total and substrate-active bacteria in highly eutrophic waters such as the Chesapeake (Tabor \& Neihof 1982, 1984, Bailey et al. 1983) and Kiel Bays (Meyer-Reil 1978) is clearly greater than in the waters off Nova Scotia (Table 5). Our abundance data are, however, similar to those reported in water samples collected in Eastern Passage, Nova Scotia (Novitsky 1983a) and overlap with those of the Kiel Bight (Meyer-Reil 1978).

As well as the abundance data, the proportion of substrate-active bacteria relative to total cell counts is also of interest. The data collected in our study are generally consistent with values presented in the recent literature (Table 5) with the exception of the bacteria which incorporate thymidine. The results of Fuhrman \& Azam (1982) and Tabor \& Neihof (1982) indicate that the number of bacteria which took up thymidine was similar to the number which incorporated other organic substrates. In contrast, our results 
indicate that counts of bacteria which incorporated thymidine were always lower than those of demonstrably active cells as determined using glutamate.

The observation that not all heterotrophically active bacteria incorporate thymidine is not new. Novitsky has reported that only a small minority of total (Novitsky 1983a) or actively growing (Novitsky 1983b) bacteria incorporated thymidine in Eastern Passage, Nova Scotia. Similarly, in one of the earliest autoradiographic studies of aquatic bacteria, Ramsay (1974) reported that 2 of 6 pure isolates did not take up thymidine. A possible reason for the difference between the abundance of glutamate- and thymidineincorporating bacteria is that a fraction of heterotrophically active cells may not be growing. The validity of this explanation has, however, been questioned by the results of Novitsky (1983b), which demonstrated clearly that bacterial growth, as measured by increase in cell numbers, could not be explained by counts of cells active with respect to several organic substrates including thymidine. This result supports the earlier findings of Ramsay, i.e. that some actively growing bacteria do not incorporate thymidine.

It is difficult to explain the substantial variation in proportion of total populations which take up labelled substrates which has been reported in the literature. Two of the factors to which autoradiography is sensitive are the concentration and specific activity of the substrate used. For this reason, the concentration ( $5 \mathrm{nM}$ ) of thymidine advocated by Fuhrman \& Azam (1980) and used by Tabor \& Neihof (1982) was used in this study. Similarly, the specific activity of the thymidine which we used $\left(77.2 \mathrm{Ci} \mathrm{mmol}^{-1}\right)$ was similar to that used by Tabor \& Neihof $\left(75 \mathrm{Ci} \mathrm{mmol}^{-1}\right)$ and was equal to or greater than that employed by Fuhrman \& Azam (40 to $60 \mathrm{Ci} \mathrm{mmol}^{-1}$ [1980] and $\geq 50 \mathrm{Ci} \mathrm{mmol}^{-1}$ [1982]).

Differences in methods between investigators may contribute to variation in results. Tabor \& Neihof (1982) compared the technique used in our study (and by Meyer-Reil 1978 and Novitsky 1983a, b) with an 'improved' technique. Although their method did produce slightly greater counts of thymidine-active bacteria ( 75.5 vs $67.3 \%$, Table 5), this change is not sufficient to explain the large differences among studies.

Based on the data available, it appears that natural bacterial populations in different habitats have different proportions of metabolically active bacteria which are able to incorporate thymidine. One aspect which remains unclear is whether some populations may exist in a state of unbalanced growth, i.e. that cells actively incorporate carbon and energy substrates for periods of time when they are not synthesizing nucleic acids. This possibility is difficult to determine for heterogenous natural bacterial populations. What is clear is that until there is strong evidence to the contrary, the case for thymidine incorporation as an universal indicator of bacterial production in natural systems must be examined cautiously.

One of the least understood limitations of autoradiography is the question of how much radioactivity an individual cell must have incorporated to expose sufficient silver grains for detection. In our study, comparison of numbers of substrate-active cells with net incorporation revealed activity-per-cell values of 1.14 to $8.94 \times 10^{-2} \mathrm{dpm}$ cell $^{-1}$ (Table 2). Although glutamate incorporation experiments were not run on a routine basis, the activity-per-cell values at 2 depths at Stn SS 9 were the lowest encountered $(1.67$ and $1.14 \times$ $10^{-2}$ dpm cell ${ }^{-1}$; Table 2). This provides evidence that the method is sensitive to lower per-cell activity levels that were characteristic of thymidine-active cells. This pattern was also observed by microscopic examination of the autoradiographic slides which showed that the cells which took up thymidine were generally characterized by greater numbers of silver grains than glutamate-active cells.

If the low counts of thymidine-incorporation cells which we observed resulted from substantial numbers of cells which incorporated thymidine in amounts below the threshold for autoradiographic detection, we would expect a correlation between percent of cells labelled and activity-per-cell values (Fuhrman \& Azam 1982). This was clearly not the case (Table 2 ).

\section{Spatial covariation of bacterial abundance and production with chlorophyll and primary production}

There was no significant correlation between bacterial variables and phytoplankton abundance or production among the 5 locations investigated. There was, however, strong spatial covariation among substrate active cell counts, thymidine incorporation and primary production in the vertical profile data collected at Stn SS 9 (Fig. 3). Despite the presence of a welldefined subsurface chlorophyll maximum (SCM), measurements of bacterial abundance, production and growth rate covaried more closely with the vertical distribution of primary production than with chlorophyll a.

The subsurface chlorophyll maximum layer is a consistent feature of the waters in the slope region off Nova Scotia during the late spring and summer and appears to be composed of light-limited but otherwise healthy phytoplankton located at the nitricline (Hargreaves 1982). Although the majority of the chlorophyl in the water column may occur in this layer, there is compelling evidence that most photosynthetic production occurs above, rather than within, the SCM 
(Herman \& Platt 1983). It is notable that our results demonstrated that the region above the SCM is also characterized by greater bacterial abundance and production rates. These results suggest that bacteria, both in abundance and production rate, are more closely coupled with phytoplankton production than with algal biomass.

\section{CONCLUSIONS}

An important consideration when evaluating thymidine-based bacterial production data is the apparent lack of utilization of this substrate by a significant number of heterotrophically active bacteria. The extent to which this factor has affected the results of published accounts in the literature is difficult to determine because few autoradiographic investigations using thymidine have been made. The lack of published data is particularly apparent for offshore marine environments. It is clear that the universality of thymidine incorporation by actively growing bacteria studied should be determined before it can be assumed that the incorporation rates measured are representative of all growing cells. Our results suggest that, at least in certain environments, thymidine-based bacterial production data may be representative of only a subpopulation of the total active bacteria.

Acknowledgements. We thank Drs. W. G. Harrison, E. L. Mills, P. J. Wangersky and L. R. Pomeroy for critical comments on an early draft of this manuscript. This research was supported by grants A-6751 (R. O. Fournier) and A-0593 (J. S. Wroblewski) from the Natural Sciences and Engineering Research Council of Canada. D. J. Douglas was supported by a Dalhousie University Graduate Fellowship.

\section{LITERATURE CITED}

Bailey, C. A., Neihoff, R. A., Tabor, P. S. (1983). Inhibitory effect of solar radiation on amino acid uptake in Chesapeake Bay bacteria. Appl. environ. Microbiol. 46: $44-49$

Brock, T. D. (1967). Bacterial growth rate in the sea: direct analysis by thymidine autoradiography. Science 155: 81-83

Coleman, A. W. (1980). Enhanced detection of bacteria in natural environments by fluorochrome staining of DNA. Limnol. Oceanogr. 25: 948-951

Daley, R. J., Hobbie, J. E. (1975). Direct counts of aquatic bacteria by a modified epifluorescence technique. Limnol. Oceanogr. 20: 875-882

Douglas, D. J. (1984). Microautoradiography-based enumeration of photosynthetic picoplankton with estimates of carbon-specific growth rates. Mar. Ecol. Prog. Ser. 14: 223-228

Ducklow, H. W., Hill, S. M. (1985a). Tritiated thymidine incorporation and the growth of heterotrophic bacteria in warm core rings. Limnol. Oceanogr. 30: 260-272
Ducklow, H. W., Hill, S. M. (1985b). The growth of heterotrophic bacteria in the surface waters of warm core rings. Limnol. Oceanogr. 30: 239-259

Ducklow, H. W., Kirchman, D. L. (1983). Bacterial dynamics and distribution during a spring diatom bloom in the Hudson River plume, USA. J. Plankton Res. 5: 333-355

Ducklow, H. W., Kirchman, D. L., Rowe, G. (1982). Production and vertical flux of attached bacteria in the Hudson River plume of the New York Bight as studied with floating sediment traps. Appl. environ. Microbiol. 43: 769-776

Faust, M. A., Correll, D. L. (1977). Autoradiographic study to detect metabolically active phytoplankton and bacteria in the Rhode River Estuary. Mar. Biol. 41: 293-305

Ferguson, R. L., Palumbo, A. V. (1979). Distribution of suspended bacteria in neritic waters south of Long Island during stratified conditions. Limnol. Oceanogr. 24: $697-705$

Ferguson, R. L., Rublee, P. L. (1976). Contribution of bacteria to standing crop of coastal plankton. Limnol. Oceanogr. 21: $141-145$

Fournier, R. O., Marra, J., Bohrer, R., Van Det, M. (1977). Plankton dyramics and nutrient enrichment of the Scotian Shelf. J. Fish. Res. Bd Can. 34: 1004-1018

Fuhrman, J. A. (1981). Influence of method on the apparent size distribution of bacterioplankton cells: epifluorescence microscopy compared to scanning electron microscopy. Mar. Ecol. Prog. Ser. 5: 103-106

Fuhrman, J. A., Azam, F. (1980). Bacterioplankton secondary production estimates for coastal waters of British Columbia, Antarctica and California. App. environ. Microbiol. 39: 1085-1095

Fuhrman, J. A., Azam, F. (1982). Thymidine incorporation as a measure of heterotrophic bacterioplankton production in marine surface waters: evaluation and field results. Mar. Biol. 66: 109-120

Griffiths, R. P., Haysaka, S. S., McNamara, T. M., Morita, R. Y. (1977). Comparison between two methods of assaying relative microbial activity in marine environments. Appl. environ. Microbiol. 34: 801-805

Hargreaves, N. B. (1982). Sub-surface chlorophyll maxima off Nova Scotia: relation to environmental parameters and zooplankton distributions. Ph.D. thesis, Department of Oceanography, Dalhousie University

Herman, A. W., Platt, T. (1983). Numerical modelling of diel carbon production and zooplankton grazing on the Scotian Shelf based on observational data. Ecological Modelling 18: 55-72

Hoppe, H.-G. (1976). Determination and properties of active metabolizing heterotrophic bacteria in the sea, investigated by means of micro-autoradiography. Mar. Biol. 36: 291-302

Hoppe, H.-G. (1977). Analysis of actively metabolizing bacterial population with the autoradiographic method. In Rheinheimer, G. (ed.) Microbial ecology of a brackish water environment. Springer Verlag, Berlin, p. 171-197

Karl, D. M. (1979). Measurement of microbial activity and growth in the ocean by rate of stable ribonucleic acid synthesis. Appl. environ. Microbiol. 38: 850-860

Karl, D. M., Winn, C. D., Wong, D. C. L. (1981a). RNA synthesis as a measure of microbial growth in aquatic environments. I. Evaluation, verification and optimization of methods. Mar. Biol. 64: 1-12

Karl, D. M., Winn, C. D., Wong, D. C. L. (1981b). RNA synthesis as a measure of microbial growth in aquatic environments. II. Field applications. Mar. Biol. 64: 13-21

Meyer-Reil, L.-A. (1978). Autoradiography and epifluorescence microscopy combined for the determination of 
number and spectrum of actively metabolizing bacteria. Appl. environ. Microbiol. 36: 506-512

Newell, S. Y., Fallon, R. D. (1982). Bacterial productivity in the water column and sediments of Georgia (U.S.A) coastal zone: estimates via direct counting and parallel measurements of thymidine incorporation. Microb. Ecol. 8: $33-46$

Novitsky, J. A. (1983a). Heterotrophic activity throughout a vertical profile of seawater and sediment in Halifax Harbor, Canada. Appl. environ. Microbiol. 45: 1753-1760

Novitsky, J. A. (1983b). Microbial activity at the sedimentwater interface in Halifax Harbor, Canada. Appl. environ. Microbiol. 45: 1761-1766

Novitsky, J. A., Morita, R. Y. (1976). Morphological characterization of small cells resulting from nutrient starvation of a psychrophilic marine vibrio. Appl. environ. Microbiol. 32: $617-622$

Novitsky, J. A., Morita, R. Y. (1977). Survival of a psychrophilic marine vibrio under long-term nutrient starvation. Appl. environ. Microbiol. 33: 635-641

Peroni, C., Lavarello, D. (1975). Microbial activities as a function of water depth in the Ligurian Sea: an autoradiographic study. Mar. Biol. 30: 37-50

Porter, K., Feig, Y. (1980). The use of DAPI for identifying and counting aquatic microflora. Limnol. Oceanogr. 25: 943-948

Ramsay, A. J. (1974). The use of autoradiography to determine the proportion of bacteria metabolizing in an aquatic environment. J. gen. Microbiol. 80: 363-373

Riemann, B., Nielsen, P., Jeppesen, M., Marcussen, B., Fuhrman, J. A. (1984). Diel changes in bacterial biomass and growth rates in coastal environments, determined by means of thymidine incorporation into DNA, frequency of dividing cells (FDC), and microautoradiography. Mar. Ecol. Prog. Ser. 17: 227-235

Strickland, J. D. H., Parsons, T. R. (1972). A practical handbook of seawater analysis. Bull. Fish. Res. Bd Can. 167

Tabor, P. S., Neihof, R. A. (1982). Improved microautoradiographic method to determine individual microorganisms active in substrate uptake in natural waters. Appl. environ. Microbiol. 44: 945-953

Tabor, P. S., Neihof, R. A. (1984). Direct determination of activities for microorganisms of Chesapeake Bay populations. Appl. environ. Microbiol. 48: 1012-1019

Van Es, F. B., Meyer-Reil, L.-A. (1982). Biomass and metabolic activity of heterotrophic marine bacteria. In: Marshall, K. C. (ed.) Advances in microbial ecology. Plenum Press, New York, 6: 111-170

Watson, S. W., Novitsky, T. J., Quinby, H. L., Valois, F. W. (1977). Determination of bacterial number and biomass in the marine environment. Appl. environ. Microbiol. 33: 940-946

Wroblewski, J. S., Cheney, J. (1984). Ichthyoplankton associated with a warm core ring off the Scotian Shelf. Can. J. Fish. Aquat. Sci. 41: 294-303

Zimmermann, R. (1977). Estimation of bacterial number and biomass by epifluorescence microscopy and scanning electron microscopy. In: Rheinheimer, G. (ed.) Microbial ecology of a brackish water environment. Springer Verlag, Berlin, p. 103-120

Zimmermann, R., Meyer-Reil, L.-A. (1974). A new method for fluorescence staining of bacterial populations on membrane filters. Kieler Meeresforsch. 30: 24-27 